\title{
DEMOCRACIA PARTICIPATIVA E ACESSO À INFORMAÇÃO COMO INSTRUMENTO DO CIDADÃO NA TUTELA COLETIVA
}

LuCAS de SOUZa LehFELD

Pós-Doutor em Direito pela Universidade de Coimbra (POR). Doutor em Direito pela PUC (SP). Docente do Programa de Mestrado em Direito da Universidade de Ribeirão Preto - SP. Coordenador do Curso de Direito do Centro Universitário Barão de Mauá. Avaliador de Cursos de Direito pelo INEP/MEC. Advogado.

\section{Neide Aparecida de Souza Lehfeld}

Pós-Doutora em Direito pela Universidade de Coimbra (POR). Doutora em Serviço Social pela PUC (SP). Consultora Nacional da Coordenação de Aperfeiçoamento de Pessoal de Nível Superior (CAPES). Docente do Programa de Mestrado em Direito da Universidade de Ribeirão Preto - SP. Diretora de Pesquisa, Ensino e Extensão da Universidade de Ribeirão Preto - UNAERP.

\section{Resumo}

Hodiernamente, a relação entre a democracia e o direito tem refletido concretamente uma sociedade fragmentada, individualista, excludente, principalmente em função da reprodução de mecanismos e instrumentos insuficientes para a legitimação de uma democracia participativa, e com isso a afirmação de um verdadeiro Estado Democrático de Direito. Assim, por meio de um diálogo entre Jürgen Habermas e Norberto Bobbio, entre o espaço público comunicativo e a observância das regras do jogo através do mínimo existencial, o cidadão é resgatado do limbo individualista fruto da emancipação política e econômica para a formação do Estado Liberal para o centro do fluxo comunicacional que caracteriza a esfera pública, não como excludente dos atores sociais de relevo que se formaram a partir da evolução para o Estado Social, mas como referencial de fonte redutível de poder que se expande da periferia das relaçóes ao centro político de opinióes e decisóes para interferir, de forma decisiva, nos caminhos da Administração, Poder Judiciário e Legislativo. Para o reconhecimento dos direitos coletivos e sua tutela, impóe-se o rompimento do paradigma individual-coletivo/público-privado. Tendo como pano de fundo o acesso à informação em seu aspecto estrito, ou seja, para efeito dos interesses coletivos e gerais previstos na Constituição Federal brasileira, conclui-se que a concepção do cidadão (indivíduo político) como titular de direitos contribui para a evolução do sistema judicial e para o reforço do acesso à devida prestação jurisdicional, na busca pela democracia substancial e participativa através dos instrumentos forjados pelo ordenamento constitucional 
para a tutela dos direitos coletivos. O estudo realizado baseou-se em pesquisa bibliografia, sendo as fontes analisadas a partir dos métodos dedutivo, indutivo, comparativo, dialético e sócio-histórico.

\section{Palavras-chave}

Democracia participativa; Acesso à informação; Tutela coletiva.

\section{Resumen}

En nuestros tiempos, la relación entre la democracia y el derecho tiene refletada concretamente una sociedad fragmentada, individualista y excluyente, debido principalmente a la reproducción de mecanismos e instrumentos suficientes para la legitimidad de la democracia participativa, y con ella la afirmación de un Estado democrático verdadero. De este modo, a través de un diálogo entre Jürgen Habermas y Norberto Bobbio, entre el espacio público comunicativo y el cumplimiento de las reglas del juego a través del mínimo existencial, el ciudadano es rescatado del limbo, resultado individualista de la emancipación política y económica para la formación del Estado Liberal, para el centro del flujo de comunicación que caracteriza a la esfera pública, no como excluyente de los actores sociales que se formaron a partir de la evolución para el Estado Social, mas como fuente reductible de poder que se expande de la periferia al centro político de opiniones y decisiones para intervenir de manera decisiva en los caminos de la Administración, Poder Judicial y Legislativo. Para el reconocimiento de los derechos colectivos y su protección y tutela, necesario es que se interrumpa y se rompa el paradigma individuo-colectivo/público-privado. Teniendo como referencia el acceso a la información en su aspecto estricto, es decir, para efectos de los intereses colectivos y generales previstos en la Constitución Federal, se concluye que el regreso al individuo político como titular de derechos, contribuye para la evolución del sistema judicial y para la mejora del acceso a la adecuada adjudicación de los derechos en la búsqueda de la democracia sustancial y participativa, a través de los instrumentos forjados por el marco constitucional para la protección colectiva. El estudio se basó en la investigación bibliográfica y las fuentes fueron analizadas desde los métodos deductivo, inductivo, comparado, socio-histórico y dialéctico.

\section{Palabras clave}

Democracia participativa; Acceso a la información; Tutela colectiva.

\section{Introdução}

Constituem-se como temática principal do presente estudo a democracia moderna e sua relaçáo com o direito, tendo o cidadão como fonte primária da legitimação do 
processo democrático e sua posição central como agente participativo, a partir do acesso à informação, dentro de um sistema comunicativo, como instrumento fundamental para sua atuação nas decisóes políticas do Estado e do acesso à Justiça para a tutela coletiva.

Constata-se, hodiernamente, que a relação entre direito e democracia reflete uma sociedade fragmentada, individualista e excludente, mediante a reprodução de mecanismos e instrumentos insuficientes para a legitimação da participação cidadã nas decisões políticas e afirmação do Estado Democrático de Direito, com o privilégio do indivíduo - em acepção negativa que lhe outorgaram várias correntes do pensamento, ou seja, fomentador de desunião, discórdia e ruptura da ordem constituída - na utilização do Judiciário para a defesa dos direitos subjetivos individuais, com a correspondente sobrecarga do sistema de prestação jurisdicional pela atomizaçáo dos conflitos, em detrimento da satisfaçáo dos interesses da coletividade, em grande parte motivados pelas promessas não cumpridas quanto aos direitos sociais.

A partir de um diálogo entre Jürgen Habermas e Norberto Bobbio, como referenciais teóricos, procurou-se estabelecer como as "regras do jogo", para o segundo, e o "espaço público comunicativo", para o primeiro, comportam os elementos imprescindíveis para o verdadeiro processo democrático, tendo como pressuposto fundamental e de viabilidade o acesso à informação.

Em seguida, analisam-se as bases para a democracia participativa mediante o acesso à informação no quadro da jurisdição, no intuito de responder a seguinte problematização: se o aparelhamento do cidadão, através de novos instrumentos e mecanismos, significa o abandono ou retrocesso no confronto com os ideais dos movimentos sociais e a própria constituição da sociedade civil no espaço público, ou constitui um reforço de garantia perante o núcleo do sistema político, na tríplice divisão da Administração, Jurisdição e formação da vontade soberana através da deliberação do Legislativo.

Para tal desafio, utilizou-se de pesquisa bibliográfica, valendo-se de autores clássicos e contemporâneos nas áreas da ciência política, direito constitucional e administrativo. A análise das fontes e construção do raciocínio foram balizadas pela utilização dos métodos indutivo, comparativo, dialético, dedutivo e sócio-histórico.

\section{Da Relação entre Democracia e Direito}

Para Paulo Bonavides (2007, p. 393), a democracia é a forma de exercício da função governativa "em que a vontade soberana do povo decide, direta ou indiretamente, todas as questôes de governo, de tal sorte que o povo seja sempre o titular e o objeto - a saber, o sujeito ativo e o sujeito passivo de todo o poder legítimo”.

No pensamento político, a evolução da concepção de democracia remete às teorias clássica, medieval e moderna, em que o cidadão, em sentido restrito (democracia 
ateniense), e a soberania popular se alternam na legitimação do Governo e, posteriormente, do Estado. Justamente essas concepçóes de cidadania e soberania popular moldaram as doutrinas políticas pós-Revolução Francesa (1789), quais sejam, do liberalismo em contraposição ao socialismo; e sobre à conotação liberal do Estado, da liberdade dos antigos que remete à esfera pública e à participação ativa no poder político, em relação à liberdade dos modernos, vinculada à esfera privada e à representação da soberania popular através de um núcleo intangível pelo Estado.

Estas são as bases nas quais se assentam a democracia representativa e o processo de democratização mais quantitativo (ampliação do sufrágio e dos órgãos político-legislativos) que qualitativo (críticas das doutrinas socialistas sobre a participação popular e o controle do poder insuficiente nas mãos do cidadão), refletindo seus efeitos nos regimes liberais democráticos.

Fundado na premissa de que pode haver direito sem democracia ( $v . g$. os regimes totalitários do século XX), mas não o contrário (democracia sem direito), surge a defesa intransigente, conforme Norberto Bobbio (1986), das "regras do jogo"1 ou "procedimentos universais". Ou seja, os modos de aquisição e exercício do poder delineados pelo direito, fruto da ação política humana. Regido pelo critério da igualdade do voto e da maioria, da presença indeclinável dos cidadãos chamados a participar, direta ou indiretamente, do processo político e dotados de condições mínimas para a decisão soberana (liberdade de opinião, expressão, reunião, associação etc.), indicados estarão os elementos básicos de uma sociedade liberal democrática, que será mais ou menos democrática a partir da adoção ampla ou restrita de tais critérios de qualificação.

Bobbio (2004, p. 1), em sua obra "Era dos Direitos", já manifestava o seu entendimento sobre a relação entre democracia e direito:

Direitos do homem, democracia e paz são três momentos necessários do mesmo movimento histórico: sem direitos do homem reconhecidos e protegidos, não há democracia; sem democracia, não existem condiçôes mínimas para a solução pacífica dos conflitos. Em outras palavras, a democracia é sociedade dos cidadãos, e os súditos se tornam cidadáos quando lhes são reconhecidos alguns direitos fundamentais [...].

Subjacente à essa relação, Celso Lafer (apud BOBBIO, 2004, p. VI) esclarece que “[...] direito e poder são as duas faces de uma mesma moeda, pois a comum exigência da eficácia se complementa com o evidente paralelismo existente entre os requisitos da norma jurídica - justiça e validade - e os do poder - legitimidade e legalidade”.

1 Bobbio, em sua obra "Dicionário Político" (1997, p. 328) afirma que a democracia perfeita e utópica deveria simultaneamente atender as regras do jogo (ou seja, a "democracia formal”) e garantir a igualdade jurídica, social e econômica, como sua finalidade primordial (“democracia substancial”). 
A afirmação dos direitos humanos, portanto, contra o abuso do exercício do poder nos conduz a outro elemento de contenção, para além dos formais da representação política: a transparência, que para Lafer (apud BOBBIO, 2004, p. VIII) consubstancia em "um direito à informação que permite a participação consciente da cidadania na vida democrática”.

Sob o mesmo prisma entende Victor Gentilli (2002, p. 42-43), para quem está implícito no pensamento de Bobbio "a compreensão de que, para se ter acesso ao Poder Público - e, por consequência, à posse de direitos - o cidadão precisa ter assegurado o acesso à informação pública”.

Corroborando essa compreensão, Bobbio (1986, p. 89) complementa:

Entende-se que a maior ou menor relevância da opinião pública entendida como opinião relativa aos atos públicos, isto é, aos atos próprios do Poder Público que é por excelência o poder exercido pelos supremos órgãos decisórios do Estado, da "res-publica", depende da maior ou menor oferta ao público, entendida esta exatamente como visibilidade, cognoscibilidade, acessibilidade e, portanto, controlabilidade dos atos que detém o supremo poder.

Isso nos leva à percepção de Jürgen Habermas (1997) sobre a inserção das pessoas privadas no mundo da vida e sujeitos da esfera pública. Afinal, participação consciente do cidadão e inserção no espaço público pressupóem requisitos mínimos de qualificação, dentre eles o acesso à informação.

O referido autor (1997) propóe uma teoria sociológica da democracia, a partir de crítica à teoria procedimental da política deliberativa e à teoria do sistema político de ação como autorregulação funcional da sociedade e demais esferas de poder - que exclui os indivíduos ou coletividades do mundo da vida, ou seja, desligados da sociedade civil, da cultura política e socialização, para um sistema destituído de "freios normativos contidos no fluxo do poder regulado pelo Estado de Direito" - capaz de "provocar déficits de legitimação e de regulação" que "favorecem uma espécie de incrementalismo muito próximo ao quietismo".

Essa nova teoria parte da garantia do nexo constitutivo entre direito e poder político através de contextos comunicacionais do mundo e da vida oriundos da esfera pública e privada. Ou seja, a legitimação do processo democrático, com fundamento na teoria do discurso, que pressupóe fluxos da periferia ao centro decisório administrativo, legislativo ou judiciário, antes de retornar ao ciclo de implementação. Para sua ideia de democracia, sustentada na ação comunicativa, deve haver uma síntese entre a garantia dos direitos humanos e o princípio republicano fundamentado na soberania do povo. (HABERMAS, 1997) 
É na esfera pública, portanto, que os fluxos de comunicação são filtrados e sintetizados para condensar as opiniốes públicas. Daí sua função de captar e tematizar os problemas da sociedade, além de intermediar a comunicação entre o sistema político e os "setores privados do mundo da vida" através do direito, numa verdadeira estrutura de comunicação. Tais conceitos estão intimamente vinculados ao processo democrático participativo discursivo e ao acesso à informação no fluxo comunicacional que se trava na esfera pública de mediação coletiva, "apoiada em direitos fundamentais" (HABERMAS, 1997, p. 101).

A concepção do cidadão, que não é reduzido à condição de eleitor, mas indivíduo que integra e participa da esfera pública e política como centro do poder democrático ${ }^{2}$, e do acesso à informação como instrumento de integração na esfera pública, com potencial de controle da Administração, não significa o menosprezo ao Estado como associaçáo política orgânica, ou de grupos intermediários com poder de identidade e mobilização, ou mesmo a prevalência do direito individual ao dever coletivo na comunhão social. Apesar dos obstáculos à realização das promessas da democracia moderna, abaixo indicados, sobrelevam os ideais que iluminaram a construção das regras do jogo e informam a ideia do "cidadão ativo" de Norberto Bobbio (2004).

É hoje dominante nas ciências sociais a orientação de estudos chamada de "individualismo metodológico", segundo o qual o estudo da sociedade deve partir do estudo das açôes do indivíduo. Não se trata aqui de discutir quais são os limites dessa orientação; mas há duas outras formas de individualismo sem as quais o ponto de vista dos direitos dos homens se torna incompreensível: o individualismo ontológico, que parte do pressuposto (eu não saberia dizer se é mais metafísico ou teleológico) da autonomia de cada indivíduo com relação a todos os outros e da igual dignidade de cada um deles; e o individualismo ético, segundo o qual todo indivíduo é uma pessoa moral. Todas essas versões do individualismo contribuem para dar uma conotação positiva a um termo que foi conotado negativamente, quer pelas correntes de pensamento conservador e reacionário, quer pelas revolucionárias. O individualismo é a base filosófica

2 Não é estranho a Norberto Bobbio (1986) a perda da autonomia dos indivíduos singulares, a substituição por grupos intermediários e sistemas neocorporativistas nas democracias representativas, com vários centros de poder e a limitação do indivíduo ao papel geral de cidadão, destituído de múltiplas funçóes na sociedade, com limitaçáo do espaço democrático. O autor anota vários obstáculos ao futuro da democracia e às promessas do ideal democrático, como o governo dos técnicos, o aumento do aparato burocrático e o baixo rendimento diante das demandas contínuas e progressivas da complexa sociedade civil. O processo de alargamento da democracia já fora notado pelo referido autor náo sob o aspecto do sufrágio, mas através da extensão da democratização que permita a participação dos interessados nas deliberaçóes de um corpo coletivo, ou seja, da passagem da democracia na esfera política para a democracia na esfera social, onde o indivíduo passa da condição de cidadão para sua condição de múltiplos status (pai; consumidor; associado etc.). 
da democracia: uma cabeça, um voto. Como tal, sempre se contrapôs (e sempre de contraporá) às concepçôes holísticas da sociedade e da história, qualquer que seja a procedência das mesmas, concepçóes que têm em comum o desprezo pela democracia, entendida como aquela forma de governo na qual todos são livres para tomar as decisóes sobre o que lhes diz respeito, e tem o poder de fazê-lo. Liberdade e poder que derivam do reconhecimento de alguns direitos fundamentais, inalienáveis e invioláveis, como é o caso dos direitos dos homem. (BOBBIO, 2004, p. 57)

Segundo José Joaquim Gomes Canotilho (2008), a noção de cidadão ativo é relevante para a teoria republicana, que reclama, como base antropológica de seu discurso, o indivíduo. Porém, não se trata de um sujeito abstêmio da modernidade liberal, mas combatente politicamente, inclusive na esfera pública, que o aproxima da noção de liberdade dos antigos.

Nas duas acepçóes dos pensadores de referência, do "cidadão ativo" de Norberto Bobbio, aos "sujeitos privados vivos e atuantes" de Jürgen Habermas, o acesso à informaçáo constitui-se como elemento fundamental para o agir comunicativo na esfera pública, bem como para resguardar as regras do jogo de maneira substancial, com um mínimo existencial que impede a formação de um sistema hermético não emancipatório ou deslegitimado, e posiciona o cidadão em situação ativa nesta relação entre a democracia e direito. Como esse princípio interage com os demais mecanismos e instrumentos da democracia participativa, e sua contribuição para a afirmação da cidadania e da justiça social no âmbito da jurisdição, são os temas a seguir analisados.

\section{Acesso à Informação e Democracia Participativa}

Democracia participativa, em contraposição à representativa, remonta à democracia direta, ou seja, a possibilidade de utilização de outros mecanismos além do sufrágio universal, o qual se funda na ótica da deliberação para a manifestação da vontade do cidadão na esfera política de decisão estatal.

Questiona, sobre o tema, David Held (apud LEAL, 2008, p. 14):

[...] uma vez que o entrelaçamento do Estado e da sociedade civil deixa poucas, ou nenhuma, das esferas da vida privada intocadas pela política, a questão da forma correta de regulamentação democrática apresenta-se vivamente. Qual forma o controle democrático deveria assumir e qual deveria ser a esfera do processo democrático de tomada de decisóes: estas se tornam questóes urgentes.

Antonio Carlos Wolkmer (2001) traça um caminho entre a democracia representativa liberal clássica, e a retomada da democracia participativa como lócus da prática e 
do poder local, diante dos seguintes fatores de crise: (a) os sucessivos descumprimentos de programas, com esvaziamento dos mandatos políticos e distanciamento das demandas reais da sociedade; (b) corrupção na classe política, com tolerância dos outros Poderes do Estado; (c) declínio de vastos setores sociais, com deterioração das condições sociais causada por ajustes e políticas desiguais; (d) complexidade das demandas e especialização técnica, com aumento das diferenças sociais e funcionais sem a capacitação dos partidos e lideranças, ainda arraigados na prática do clientelismo; (e) crise dos grandes discursos de legitimação, como socialismo, sujeito coletivo, Estado-Nação; e (f) influência dos meios de comunicação, que poderiam contribuir para a democratização da política e formação ética da opinião pública. Propóe um novo paradigma, com prioridade na ação humana dos novos sujeitos sociais, descentralização democrática e participação da sociedade civil, sem a exclusão das limitadas e insuficientes regras formais (partidos políticos; açóes da maioria; sistema de votos) e sim com a inclusão de novos processos de democracia direta (participação orçamentária; gestão compartilhada e sistema de conselhos) capazes de conviver com a democracia por delegação, com privilégio ao poder local e não meramente formal.

Para a democracia participativa e afirmação da cidadania concorrem vários instrumentos e mecanismos, mas não pretendemos discorrer, neste espaço, sobre o direito à informação como o reverso da moeda da liberdade de imprensa e a constituição dos meios de comunicação - e suas funçôes de vigiar o ambiente sociopolítico, definir as questóes significativas e permitir a expressão das plataformas políticas e diálogo permanente entre o público e os detentores do poder, incentivar os cidadãos a se envolver no processo político, resistir aos fluxos externos contra sua independência e respeitar os destinatários da comunicação - bem como as suas implicaçóes na (des)informação e (de)formação da vontade popular, que foram com absoluta propriedade tratadas por Habermas (1997, p. 113), in verbis:

Quando tomamos consciência da imagem difusa da esfera pública veiculada pela sociologia da comunicação de massa, que aparece submetida ao poder e à dominaçáo dos meios de comunicação de massa, cresce nosso ceticismo com relação às chances de a sociedade civil vir a exercer influência sobre o sistema político. Todavia, tal avaliação vale somente para a uma esfera pública em repouso. Pois, a partir do momento em que acontece uma mobilização, as estruturas sobre as quais se apoia a autoridade de um público que toma posição começam a vibrar. E as relaçóes de forças entre a sociedade civil e o sistema político podem sofrer modificaçóes.

Evidente que o acesso à informação, em sentido lato, é fundamental - direito-meio - para que a democracia representativa ou participativa, através de seus instrumentos e mecanismos, convencionais ou não, materiais ou formais, de "controle social ou político -legislativo" (LEAL, 2008, p. 22), ou jurisdicional ( $v$ g. exercício do sufrágio; referendo; plebiscito; iniciativa de lei; consulta popular; audiência pública; orçamento participativo; 
ação popular; participação no Tribunal do Júri, e em Conselhos e Fóruns da Administração e da Jurisdição como Conselho da República, Conselho Nacional de Justiça e Conselho Nacional do Ministério Público etc.), não se transforme em espaço de poucos, contaminado pelos déficits de legitimação e efetividade.

[...] densificação da democracia à sociedade brasileira implica, salvo melhor juízo, não só em oportunidades materiais de acesso da população à gestão pública da comunidade, mas fundamentalmente de fórmulas e práticas de sensibilização e mobilização dos indivíduos e das corporações à participação, através de rotinas e procedimentos didáticos que levem em conta as diferenças e especificidades de cada qual. (LEAL, 2008, p. 18).

Ressaltam-se, portanto, o acesso à informação e suas funçóes e ponte sistêmica entre os direitos fundamentais e a democracia participativa. Segundo Gentilli (2002), uma porta de acesso a outros direitos e pressuposto da cidadania.

Entretanto, o acesso à informação, nesta acepção restrita, é visto como forma de controle social do Estado pelo cidadão, que assume posição ativa na construção de sua realidade e se afasta da condição de mero destinatário da informação produzida pelos meios de comunicação, além de promover a qualificação e facilitação do acesso à devida prestação jurisdicional para a tutela da coletividade, com reflexos da esfera pública sobre a política, ou seja, com o fim de estabelecer um fluxo de comunicação para afirmação da democracia participativa e do Estado Democrático de Direito.

\section{Acesso à Informação: Contexto Jurídico-Normativo Internacional, Consti- tucional e Infraconstitucional}

A própria noção de democracia pressupóe transparência nas relações entre o Estado e o cidadão, através de um fluxo comunicacional contínuo e de via dupla, entre a esfera privada, o espaço público e o político, para a máxima legitimação da representação e participação.

Essa percepção imanente ao sistema democrático, representativo ou participativo, formal ou substancial, sobre o acesso à informação como pressuposto básico aos procedimentos de legitimaçáo e, portanto, um direito fundamental ao exercício de outros direitos, civis, políticos e sociais, foi incorporada por convençôes e tratados internacionais assinados e ratificados pelo Brasil, como a Declaração Universal dos Direitos Humanos ( v. g., "Art. XIX. Todo ser humano tem direito à liberdade de opinião e expressão; este direito inclui a liberdade de, sem interferência, ter opinióes e de procurar, receber e transmitir informações e ideais por quaisquer meios e independentemente de fronteiras"), a Convenção das Naçôes Unidas Contra a Corrupção (v. g., "Art. 10 Tendo em conta a necessidade de combater a corrupção, cada Estado Parte [...] adotará medidas que sejam 
necessárias para aumentar a transparência em sua administração pública, inclusive no relativo a sua organização, funcionamento, e processos de adoção de decisões, quando proceder”), a Declaração Interamericana de Princípios de Liberdade de Expressão (v.g. "Item 4. O acesso à informação mantida pelo Estado constitui um direito fundamental de todo indivíduo. Os Estados têm obrigações de garantir o pleno exercício desse direito") e o Pacto Internacional dos Direitos Civis e Políticos (v. g., "Art. 19. Toda pessoa terá direito à liberdade de expressão; esse direito incluirá a liberdade de procurar, receber e difundir informaçôes e ideias de qualquer natureza").

Essa correlação entre sistema democrático e direitos fundamentais é ressaltada por Sarlet (2012, p. 61), uma vez que estes são

pressuposto, garantia e instrumento do princípio democrático da autodeterminação do povo por intermédio de cada indivíduo, mediante o reconhecimento do direito de igualdade (perante a lei e de oportunidades), de um espaço de liberdade real, bem como por meio da outorga do direito à participação (com liberdade e igualdade), na conformação da comunidade e do processo político, de tal sorte que a positivação e a garantia do efetivo exercício de direitos políticos (no sentido de direitos de participação e conformação do status político) podem ser considerados o fundamento funcional da ordem democrática e, nesse sentido, parâmetro de sua legitimidade.

Na Constituição Federal Brasileira de 1998 (CF/88), embora o acesso à informação permeie a concepção de inúmeras garantias fundamentais, o direito foi tutelado no Capítulo I - Dos Direitos e Deveres Individuais e Coletivos - do Título II - Dos Direitos e Garantias fundamentais.

Art. 5.'. [...]

XXXIII - Todos têm direito a receber dos órgãos públicos informações de seu interesse particular, ou de interesse coletivo ou geral, que serão prestadas no prazo da lei, sob pena de responsabilidade, ressalvadas aquelas cujo sigilo seja imprescindível à segurança da sociedade e do Estado.

Numa interpretação desarmada do referido dispositivo permite afirmar que o acesso à informação pública é regra e o sigilo a exceção (amplitude); ao direito do cidadão corresponde o dever do Estado (destinatário); e as informaçôes se voltam a proteger o interesse particular, coletivo ou geral (finalidade).

Em sede infraconstitucional, a legislação federal contemplou o acesso à informação, que se liga umbilicalmente à publicidade ${ }^{3}$ dos atos e açóes administrativas como

3 Assevera Mendes (2014), que o princípio da publicidade se liga ao direito de informação do cidadáo e ao dever de transparência do Estado, em conexão direta com o princípio democrático, numa dúplice vertente 
instrumento de democracia participativa, no controle sobre a execução do orçamento, a transferência de recursos e sua aplicação (cf. art. 48-A, da Lei de Responsabilidade Fiscal - Lei Complementar n. ${ }^{\circ}$ 101/2000), ou para disciplinar a Política Nacional de Arquivos Públicos e Privados (art. $4 .^{\circ}$ da Lei n. ${ }^{\circ} 8.159 / 1991$ ), por exemplo.

Entretanto, a disciplina legal de maior relevância para a concreção do direito fundamental previsto no art. 5. ${ }^{\circ}$, inciso XXXIII, da CF/88 foi a publicação da Lei n. ${ }^{\circ} 12.527$, de 18.11.2011 (com a entrada em vigor em 16.05.2012), conhecida como "Lei de Acesso à Informação" com amplo potencial emancipatório e de tutela coletiva de direitos.

Em síntese, a referida lei promove as garantias do direito ao acesso, disciplina regras sobre a divulgação e rotina, como o processamento dos pedidos, recursos contra a negativa, restriçôes fundadas no sigilo dos dados, tratamento de informaçóes pessoais e responsabilidade dos agentes públicos. Podem ser consideradas, no limite do presente estudo, algumas regras de importância trazidas pela Lei n. ${ }^{\circ}$ 12.527/2011.

O acesso à informação, no referido diploma, é direito fundamental para o controle social, em conformidade com os princípios básicos da Administração Pública, a partir da ampliação dos destinatários (Administração direta e indireta dos Poderes Executivo, Legislativo, Judiciário e Ministério Público, além de entidades privadas sem fins lucrativos destinatárias de recurso ou subvençóes), da noção de informação (para abranger o suporte - documento), e da vedação à qualquer restrição para a informação necessária à tutela judicial ou administrativa de direitos fundamentais, com preponderância do acesso público ao resguardo às informaçóes pessoais nessas hipóteses, de modo a incentivar a participação popular.

Neste sentido, essa exigência legal proporcionou aprimoramento dos canais de comunicação entre Estado e cidadão. Isso pode ser constatado pelo avanço na implantação de plataformas digitais, como sites governamentais brasileiros que publicizam e cruzam informaçóes sobre o desenvolvimento de processos nas searas legislativa, administrativa e judiciária, o que constituiu um cenário mais favorável a uma participação democrática direta.

Cabe ressaltar que há ainda deficiências que necessitam ser sanadas, apesar da evolução do acesso à informação como direito fundamental. A exigência de transparência trazida pela Lei n. ${ }^{\circ}$ 12.527/2011 não evitou, por exemplo, práticas de corrupção de grande monta, como as investigadas, nos dias atuais, pelo Ministério Público e Justiça Federal, na maior empresa brasileira, Petrobrás. A existência de diversos mecanismos de controle institucional e social náo foram suficientes para evitar, até o momento, o mais significativo prejuízo ao patrimônio e erário públicos.

de participação e controle, pelo cidadão, e conformação da administração aos princípios de atuação, de outro. 
Sob outro prisma, a corrupção na Petrobrás e em outras entidades e órgãos públicos brasileiros só veio à tona graças a institutos que de forma direta ou indireta decorrem desse aprimoramento do sistema comunicativo na esfera público-privada, com a articulaçáo e acesso a informaçóes, como: a) delação premiada, que permite se chegar à coautoria ou participação de crimes por meio das informaçôes fornecidas à autoridade pública pelo indiciado ou acusado (v.g. Código Penal - arts. 159, \$4. ${ }^{\circ}$; e 288, Parágrafo Único; Lei do Crime Organizado - Lei n. ${ }^{\circ} 9.034 / 05$, art. $6 .^{\circ}$; Lei dos Crimes contra o Sistema Financeiro Nacional - Lei n. ${ }^{\circ}$ 7.492/86, art. 25, $\$ 2 .^{\circ}$; Lei dos Crimes de Lavagem de Capitais - Lei n. ${ }^{\circ} 9.613 / 88$, art. $1^{\circ}, \$ 5^{\circ}$; Lei dos Crimes contra a Ordem Tributária e Econômica - Lei n. ${ }^{\circ}$ 8.137/90, art. 16, Parágrafo Único); e b) acordo de leniência, que possibilita à autoridade pública investigar a prática de atos ilegais a partir da colaboração, por meio de informaçốes e documentos comprobatórios, de pessoas jurídicas envolvidas (v.g. Lei Anticorrupção - Lei n. ${ }^{\circ}$ 12.846/2013, arts. 16 e 17; Lei do Sistema Brasileiro de Concorrência - Lei n. ${ }^{\circ} 12.529 / 2011$, arts. 86 e 87).

Essa amplitude quanto ao acesso à informação, pelo contexto legislativo nacional brasileiro, possibilita vislumbrar um novo enfoque do exercício da cidadania e consequente afirmação da democracia para além da formal representação, com reflexos na relação cidadão-administração e cidadão-jurisdição, tema a seguir abordado.

\section{Acesso à Informação e Devida Prestação Jurisdicional: Participação-Ci- dadã na Tutela Coletiva}

$\mathrm{O}$ acesso à Justiça ${ }^{4}$ tomou impulso novo com a Constituição Federal Brasileira de 1988 (art. 5. ${ }^{\circ}$ XXXV) e seu texto repleto de promessas, ao lado de uma sociedade carente de direitos civis, políticos e sociais básicos (ou seja, de todas as geraçóes (ou dimensóes) de direitos fundamentais), refletiu na consolidação do Poder Judiciário e do processo como instrumento de participação democrática.

Com propriedade, Canotilho (2008, p. 72) observa que o processo postula "uma imbricação material com os direitos fundamentais", sob à tríplice perspectiva: (a) como instrumento de proteção e realização dos direitos fundamentais; (b) como instrumento adequado e justo para a limitação ou restrição dos direitos fundamentais; e (c) como lócus do exercício dos direitos, liberdades e garantias.

4 Segundo Cappelletti e Garth (1988), na clássica obra sobre o acesso à Justiça, a segunda onda para a pacificação de conflitos dizia respeito à representação jurídica para os interesses difusos, enquanto a terceira tinha o enfoque no acesso à Justiça. Cabe ressaltar que concebemos o acesso à Justiça como a devida prestaçáo jurisdicional, a partir de princípios constitucionalmente tutelados como o devido processo legal formal e substancial, celeridade processual etc. 
A complexidade social e a demanda por novos direitos ${ }^{5}$, negados pelo Estado Social a contingentes expressivos da população, sequer reconhecidos ou capacitados para o exercício, sobretudo os direitos sociais que requerem uma intervenção direta do Estado "para sua proteção efetiva [...]" (BOBBIO, 2004, p. 67), geraram uma das consequências visíveis que parece suscitar a denominada crise do Judiciário, da instrumentalidade do processo e a efetividade como seu escopo institucional, qual seja, o individual solapando o coletivo na distribuição equitativa da Justiça, ante à prevalência dos conflitos fundados nos direitos subjetivos individuais, de modo a provocar a sobrecarga do sistema que se relaciona com a crise da modernidade democrática e o esvaziamento do espaço público.

Sobre a judicialização da política e a transferência do lócus de decisão para o Judiciário, como último refúgio ao distanciamento da vida institucional e das instâncias políticas tradicionais - partidos; associaçóes; família, Garapon (2001, p. 44-49) conclui que "O sucesso da Justiça é inversamente proporcional ao descrédito que afeta as instituições políticas clássicas, causado pela crise de desinteresse e pela perda do espírito público”.

Em contraponto, Leal (2008, p. 9) entende que

o esgarçamento da esfera pública não como lócus do Estado, mas da política, espaço em que todos têm o dever e direito de participar de forma efetiva, não implica a substituição ou derrocada das esferas institucionais de representação política tradicionais (Executivo, Legislativo e Judiciário), até porque, como adverte Habermas, o poder comunicativo não pode substituir a lógica sistêmica da burocracia, e a solidariedade não pode substituir o poder administrativo, na medida em que a responsabilidade da tomada de decisão só pode ser garantida eficazmente pelo processo político institucionalizado (sob pena de anarquia desgovernada).

Para Habermas (1997), a teoria do sistema arruína a base de legitimação do Estado Democrático de Direito por impedir o fluxo comunicacional da periferia através da política e direito - autorreferenciados, com linguagem própria e hermética, enquanto

as políticas negociadas neocorporativisticamente entram em conflito com grupos da periferia da sociedade, francamente organizada e protegida apenas através de direitos fundamentais; isso é consequência de

5 Habermas (1997, p. 76-77) menciona Helmut Wilke, para depois refutar sua ideia de equilíbrio intersistêmico com base na deslegitimação, ao resumir a sociedade integrada proposta por ele: "A proteção jurídica fornece exemplos para os novos bens coletivos da sociedade de alto risco: a proteção contra a destruição do meio ambiente, contra a contaminação atômica ou modificação letal da herança genética e, em geral, a proteçâo contra os efeitos colaterais e não controlados que podem ser causados por instalaçōes técnicas, produtos farmacêuticos, experimentos científicos etc. [...]. Dessa maneira, o direito funciona como catalisador de transformaçóes internas". Em interessante capítulo, Wolkmer (2012) trata da questão histórica dos "novos" direitos, sua problematização e seus fundamentos, assim como dos instrumentos jurídicos capazes de garantir a tutela dos "novos" direitos. 
uma distribuição desigual de ressarcimentos individuais e do fato de que a privação de bens coletivos atinge de modo seletivo as diferentes classes sociais. (HABERMAS, p. 82, v. II)

Sob o influxo descontrolado de demandas individuais, de intensa litigiosidade como resultado da negação cotidiana, pelo Estado, das promessas sociais catalisadas pela Lei Maior - que para Bobbio (2004) são grandiosas, mas de miserabilidade em suas realizaçóes - suscitou o interesse participativo de "novos" atores, como entidades de classe, as organizações sindicais e não governamentais, ao lado de "novos" direitos.

No Brasil, a Constituição Federal de 1988 conferiu à tutela coletiva (v.g. ação civil pública, açóes coletivas, mandado de segurança coletivo, ação popular, ação declaratória de constitucionalidade e direta de inconstitucionalidade) um sistema de legitimação aberta e a indicação dessa orientação emana, por exemplo, do tratamento conferido ao Ministério Público, a quem compete promover o inquérito civil e a ação civil pública para a proteção do patrimônio público e social, do meio ambiente e de outros interesses difusos e coletivos (art. 129, inciso III, da CF/88), desde que a legitimação não impeça a de terceiros, nas mesmas hipóteses, segundo o disposto na Constituição (art. 129, $\$ 1 .^{\circ}$, da CF/88).

Em outra passagem, a Lei Maior reforça essa intelecção ampliativa ao tratar da ação de inconstitucionalidade de leis e atos normativos em face da Constituição Estadual, ao vedar a atribuição da legitimação para agir a um único órgão (art. 125, $\$ 2 .^{\circ}$, da CF/88).

A opção constitucional é decorrência lógica da natureza própria dos interesses metaindividuais, desprovido de titularidade imediata e singular, no sentido material, porquanto disperso numa coletividade de pessoas indeterminadas ou indetermináveis.

Na clássica lição de Cappelletti (1977, p. 135), esses novos interesses, que "sem serem públicos em senso tradicional da palavra, são, no entanto, coletivos: desses ninguém é titular, ao mesmo tempo que todos os membros de um dado grupo, classe, ou categoria, deles são titulares. A quem pertence o ar que respiro?”.

Entretanto, a participação do cidadão na defesa da coletividade e dos interesses transindividuais sempre foi vista com reservas. Limitado à tutela atomizada de natureza particular, como mero direito subjetivo, o cidadão foi alijado do processo coletivo ou, ao menos, de sua participação ampla e efetiva, restringida sua legitimação à ação popular (art. 5. ${ }^{\circ}$, inciso LXXIII, da CF/88)

Art. 5. ${ }^{\circ}[\ldots]$

LXXIII - Qualquer cidadão é parte legítima para propor ação popular que vise a anular ato lesivo ao patrimônio público ou de entidade de que o Estado participe, à moralidade administrativa, ao meio ambiente e ao 
patrimônio histórico e cultural, ficando o autor, salvo comprovada má-fé, isento de custas judiciais e do ônus da sucumbência

O sistema da Lei da Ação Civil Pública (Lei n.o 7.347/85), em conjugação com a Constituição Federal de 1988 e o Código de Defesa do Consumidor (Lei n. o 8.078/1990), constroem a legitimação mista, com a indicação legal da iniciativa por órgãos públicos (Ministério Público; Defensoria; União, Estados e Municípios etc.) e grupos intermediários da sociedade (associaçóes; sindicatos). Atrás dessa ideologia é possível afirmar a desconfiança quanto à participação do cidadão. A ação popular, embora se volte ao controle da Administração Pública por meio do Poder Judiciário, é restrita quanto aos legitimados ativo - cidadão, que no sentido jurídico trazido pela própria lei disciplinadora (Lei n. $\left.{ }^{\circ} 4.717 / 65\right)$ é o indivíduo dotado de capacidade política ativa, o eleitor - e passivo, e quanto ao objeto (meio ambiente; patrimônio público, histórico e cultural; moralidade administrativa). Portanto, não abrange todo e qualquer interesse difuso e coletivo (como consumidor; saúde pública etc.), na acepção constitucional que informa a defesa dos direitos coletivos mediante o instrumento da ação civil pública.

Esse legitimação deficitária para a defesa, pelo cidadão, de outros interesses difusos e coletivos, bem como a limitação quanto ao destinatário da pretensão, não foram adotados, por exemplo, pela Constituição portuguesa, que outorgou ao cidadão poderes mais amplos. Abaixo alguns dispositivos que refletem essa amplitude:

Art. 9. São tarefas fundamentais do Estado [...] c) Defender a democracia política, assegurar e incentivar a participação democrática dos cidadãos na resolução dos problemas nacionais.

Art. $109 .^{\circ}$ A participação directa e activa de homens e mulheres na vida política constitui condição e instrumento fundamental de consolidação do sistema democrático, devendo a lei promover a igualdade no exercício dos direitos cívicos e políticos e a não discriminação em função do sexo no acesso a cargos politicos.

Art. 267. [... 5. O processamento da actividade administrativa será objecto de lei especial, que assegurará a racionalização dos meios a utilizar pelos serviços e a participação dos cidadãos na formação das decisões ou deliberaçôes que lhes disserem respeito.

Art. 268. 1 . Os cidadáos têm o direito de ser informados pela Administraçáo, sempre que o requeiram, sobre o andamento dos processos em que sejam directamente interessados, bem como o de conhecer as resoluções definitivas que sobre eles forem tomadas. [...] 5. Os cidadãos têm igualmente direito de impugnar as normas administrativas com eficácia externa lesivas dos seus direitos ou interesses legalmente protegidos. (PORTUGAL, 2005). 
$\mathrm{O}$ acesso à informação, neste sentido, possibilita ao cidadáo avançar sua participação na defesa dos interesses da coletividade em âmbito jurisdicional, além de interferir na atividade legislativa e administrativa, como instrumento de sua expressão democrática. Explicamos.

Ao permitir que o cidadáo, em sentido amplo (e náo meramente jurídico, como eleitor), tenha acesso a informações antes confinadas à burocracia estatal, resguardada à matéria sigilosa, garantindo-lhe prioridade na defesa dos direitos fundamentais ou afastando qualquer restrição à informação no resguardo dos direitos humanos, o legislador contemplou-o com uma ferramenta poderosa que permite obter, por exemplo, dados, informações e documentos dos órgãos públicos, de interesse geral ou coletivo, idênticos aos propiciados ao Ministério Público, via poder requisitório consubstanciado no inquérito civil ou mesmo às associaçóes legitimadas.

Ainda que se conclua que o exercício da tutela coletiva não é conferido em sua integralidade ao cidadão, em razão do sistema jurídico-normativo sobre o tema, infere-se que o acesso à informação, além de contrapor o cidadão ao Estado, este obrigado a garanti-lo como direito fundamental em seu aspecto material (portanto, um direito difuso na coletividade), permite superar inúmeros óbices declinados à iniciativa individual no campo processual, pois, dentre outras funçôes: (a) previne litígios, uma vez que o acesso à informação ou documento pode exaurir a pretensão do interessado sem necessidade de se valer de vias judiciais; (b) qualifica a prova, já que autoriza a adequada instrução para conhecimento da amplitude do interesse tutelado; (c) qualifica o cidadão, no sentido de dotá-lo de representatividade adequada para a tutela coletiva; e (d) facilita o acesso à devida prestação jurisdicional, e fortalece a tutela coletiva como instrumento de pacificaçáo social e democracia participativa.

Em contraposição ao isolamento e apatia ou à "passividade cívica" (LEAL, 2008, p. 24) de sua relação com as instituiçóes e mecanismos tradicionais da democracia representativa, o resgate do cidadão não resulta em desafetação, individualismo que redunda no "paradigma liberal-individualista-normativista" (STRECK, 2009, p. 17), retirada da esfera privada do mundo da vida e da esfera pública na qual se inter-relacionam os demais atores da ação comunicativa (como os movimentos sociais, grupos de pressão, escola, trabalho, a própria sociedade civil etc.) para a tomada de decisóes, mas ressaltar a importância do foco sobre a origem do poder. Como observa Tejerina (2005, p. 94-95):

Así, junto al sentido tradicional de la separación entre lo público-político y lo privado-personal aparecen nuevos sentidos: a) cuando se afirma que lo público no existe sin la participación de lo privado, luego la acción política implica necesariamente 'mi' contribución personal; b) cuando se afirma que lo político es profundamente personal, puesto que la búsqueda de coherencia personal exige la acción pública (como toma de conciencia 
de tu forma de vida frente a un problema general); c) cuando se afirma que lo político es lo que afecta a lo íntimo y, por lo tanto, sólo la transformación de lo íntimo es auténticamente político (lo que cada uno puede hacer en su vida personal como parte de una lucha diaria). Estos sentidos inducen a la participación en la movilización social, la emergencia de nuevos sentidos de la ciudadanía en las condiciones de individualización y de la identidad colectiva características de la sociedad contemporánea, en una constante redefinición de los límites de la esfera pública.

Neste sentido, o exercício da cidadania demanda essa redefinição dos limites da esfera pública-política, bem como um novo sentido à sua relação com o âmbito privado -pessoal. Para Calmon de Passos (2005, p. 14), trata-se da cidadania plena, que:

[...] engloba mais que direitos humanos, porque, além de incluir os direitos que a todos são atribuídos, em virtude de sua condição humana, abrange, ainda, os direitos políticos. Correto, por conseguinte, falarmos numa dimensão política, numa dimensão civil e numa dimensão social da cidadania. Ser cidadão implica na efetiva atribuição de direitos nas três esferas mencionadas, porque careceria de sentido participar do governo sem condiçôes de fazer valer a própria autonomia, bem como sem dispor de instrumentos asseguradores das prestaçôes devidas pelo Estado, em nome da igualdade de todos.

Para tanto, a efetividade do acesso à informação como direito fundamental, e, sobretudo, como instrumento de tomada de decisóes pelo cidadão, impóe às instituiçôes públicas e privadas (principalmente as dotadas de caráter público) adequação dos canais e formas de comunicação às demandas sociais, em verdadeiro processo de sensibilização e ampliação da participação-cidadã nas esferas juspolíticas e legislativas do Estado, principalmente quanto à defesa dos interesses coletivos.

Essa parceria público-privada somente se mostra possível com a ampliação do acesso do cidadão às instâncias de decisão política. Nada mais do que uma legitimação do processo político dentro de um regime democrático, em que pese a transparência e a lisura das atividades governamentais voltadas à promoção social e à distribuição da justiça. Um compromisso ético que, de um lado, promove um consenso social quanto às prioridades estabelecidas pela autoridade pública na prestação de suas atividades, dentro das restriçóes orçamentárias; de outro, institui limitaçóes a atos arbitrários e em desacordo com os direitos e garantias resguardados pela Constituição Federal brasileira.

\section{Conclusões}

Procurou-se apresentar, neste estudo, reflexóes fundamentadas de como o acesso à informação perpassa a relação cidadão-administrador, cidadão-legislador e cidadão-juiz, numa posição central na concepção moderna entre democracia e direito. 
O círculo virtuoso que se estabelece a partir do acesso à informação (num "espaço público comunicativo" habermasiano) pelo cidadão ativo (sob à ótica de Norberto Bobbio) se estende à sua condição de sujeito coletivo e seu lócus na esfera pública, e o qualifica para o exercício permanente da democracia participativa, com a utilização de seus mecanismos e instrumentos fundamentais para a construção da justiça social.

Quanto à satisfação dos direitos coletivos lato sensu previstos na Constituição Federal brasileira, conclui-se que o aprimoramento dos canais de comunicação é fundamental para que se tenha controle social pelo cidadão da condução estatal (e de instituiçóes privadas de caráter público), e consequentemente da res publica, a fim de promover decisóes políticas e jurisdicionais legitimadas pelo interesse público.

Para a efetividade do acesso à informação como direito fundamental, em uma democracia participativa, torna-se imprescindível a adequação dos canais e formas de comunicação das instituiçóes públicas e privadas, no intuito de atender as demandas sociais e ampliar o campo de participaçáo do cidadão como agente protagonista, ativo, quanto às decisóes juspolítica e legislativas estatais, especialmente na tutela dos interesses coletivos a partir da devida prestação jurisdicional.

\section{Referências}

BOBBIO, N. A era dos direitos. Trad. Carlos Nelson Coutinho. 13 ed. reimp. Rio de Janeiro: Elsevier, 2004.

. Entre duas Repúblicas. Às origens da democracia italiana. Trad. Mabel Malheiros Bellati. Brasília: UnB, 2001.

. Estado, Governo e sociedade. Para uma teoria geral da política. Trad. Marco Aurélio Nogueira. 3 ed. Rio de Janeiro: Paz e Terra, 1987.

. O futuro da democracia: uma defesa das regras do jogo. Rio de Janeiro: Paz e Terra, 1986.

BOBBIO, N.; MATTEUCCI, N.; PASQUINO, G. Dicionário de política. Trad. Carmen C. Varriale et al. 10 ed. Brasília: UnB, 1997.

BONAVIDES, P. Democracia direta, a democracia do terceiro milênio. In: RIBEIRO, L. L. G.; BERARDI, L. A. A. (Org.) Estudos de direito constitucional. Em homenagem à professora Maria Garcia. São Paulo: IOB-Thomson, 2007.

CALMON DE PASSOS, J. J. Cidadania tutelada. In: FERREIRA, L. A. C. (Org.). Hermenêutica, cidadania e direito. Campinas: Millennium, 2005.

CANOTILHO, J. J. G. Estudos de direitos fundamentais. Sáo Paulo/Portugal: RT/ Coimbra Editora, 2008. 
CAPPELLETTI, M. Formaçóes sociais e interesses coletivos diante da Justiça civil. Revista de Processo, São Paulo, RT, n. 5, p. 128-159, jan.-mar. 1977.

; GARTH, B. Acesso à Justiça. Trad. Ellen Gracie Northfleet. Porto Alegre: Sergio Antonio Fabris, 1988.

CASQUETE, J. El poder de la calle: ensayos sobre a acción colectiva. Madrid: Centro de Estudios Políticos y Constitucionales, 2006. (Colección Estudios Políticos).

GARAPON, A. O juiz e a democracia: o guardiāo das promessas. Trad. Maria Luiza de Carvalho. 2 ed. Rio de Janeiro: Revan, 2001.

GENTILLI, V. O conceito de cidadania, origens históricas e bases conceituais: os vínculos com a Comunicação. Revista Famecos, Porto Alegre, n. 19, dez. 2002.

HABERMAS, J. Direito e Democracia: entre facticidade e validade. Trad. Flávio Beno Siebeneichler. Rio de Janeiro: Tempo Brasileiro, 1997. v. I e II.

LEAL, R. G. Esfera pública e participação social: possíveis dimensóes jurídico-políticas dos direitos civis de participação social no âmbito da gestão dos interesses públicos no Brasil. Revista Eletrônica sobre a Reforma do Estado (Rere), Salvador, Instituto Brasileiro de Direito Público, n. 13, mar.-maio 2008. Disponível em: <http:// www.direitodoestado.com.br/rere.asp>. Acesso em: 10 mar. 2015.

LEHFELD, L. S. Modalidades de participação-cidadã no horizonte de concreção de direitos. In: FERREIRA, L. A. C. (Org.). Hermenêutica, cidadania e direito. Campinas: Millennium, 2005.

MENDES, G. F.; BRANCO, P. G. G. Curso de direito constitucional. 9. ed. rev. e atual. São Paulo: Saraiva, 2014.

PORTUGAL. Constituição da República Portuguesa. VII Revisão Constitucional. Portugal: Assembleia Legislativa, 2005. Disponível em: <http://www.parlamento. pt/Legislacao/Documents/constpt2005.pdf>. Acesso em: 12 maio 2015.

SARLET, I. W. A eficácia dos direitos fundamentais: uma teoria geral dos direitos fundamentais na perspectiva constitucional. 11 ed. rev. e atual. Porto Alegre: Livraria do Advogado, 2012.

SILVA, J. A. Comentário contextual à Constituição. 9. ed. São Paulo: Malheiros, 2014.

STRECK, L. L. Hermenêutica Jurídica e(m) crise. Uma exploração hermenêutica da construção do direito. 5 ed. Porto Alegre: Livraria do Advogado, 2009.

TEJERINA, B. Movimientos sociales, espacio público y ciudadanía: los caminos de la utopía. Revista Crítica de Ciências Sociais, Lisboa, Centro de Estudos Sociais, n. 72 , out. 2005. 
WOLKMER, A. C. Do paradigma político da representaçấo à democracia participativa. Revista Sequência, Florianópolis, UFSC, n. 42, p. 83-98, 2000.

; LEITE, J. R. M. (Org.). Os "novos” direitos no Brasil: natureza e perspectivas - Uma visão básica das novas conflituosidades jurídicas. 2 ed. São Paulo: Saraiva, 2012. 